\title{
Digital Banking Services Awareness and its Preferences: HDFC Bank at Moradabad Region
}

\author{
Vipin Jain, Chanchal Chawla, Manoj Agarwal, Rachit Agarwal, Vibhor Jain
}

\begin{abstract}
Almost the whole world has been caught up in digitalization in recent years. Therefore, it could not stay behind the banking sector. It is time for cashless banking, which must be met by all the banks. HDFC Bank has developed a number of virtual banking facilities such as the net banking industry, Payz app, Chillr, etc., as the privately held pioneer in world class banking. Nevertheless, in order to capture the attention of the consumer, the focus of this research paper is on the creating a strong digital footprint on the market. This study is centered on an experimental study to evaluate people's awareness of HDFC banking products and their preferences.
\end{abstract}

Keywords: Banking Digital Banking, Internet Banking, HDFC Bank, Digitalization, HDFC Bank.

\section{INTRODUCTION}

Changing consumer habits and the new competitive landscape create pressure to adapt innovation on every day basis to remain relatively viable in the market. In the digitization process, the banking sector has also become a part of the race. This industry is also unable to stay in a market where it is transformed in its entirety. Banks are not generally known to be quick movers. But they, especially private sector banks, have introduced digital banking facilities, due to the growing competition in the industry. Different banks are responding with different approaches and with different speed to this new challenge but not all companies understand what it means to turn them into a digital bank. They also implemented many innovative banking approaches with a tap and make them uncomfortable. There's no need to visit the bank branch for small details such as understanding the balance of the account and seeking advice on investment. These banks, net banking and mobile banking all provide easier access to different banks. In remote areas where banking facilities had previously not been established, the ATMs were also installed. In addition to launching intelligent cards such as a credit card or a debit card, recharge and bill payments are available for customers as part of digital banking services easily while sitting at home and offering better deals and discounts. The banks of the public sector are highly sluggish

Revised Manuscript Received on November 05, 2019.

Dr. Vipin Jain, Director and Professor, Teerthanker Mahaveer Institute of Management and Technology (TMIMT), Teerthanker Mahaveer University, Moradabad, UP.

Dr. Chanchal Chawla, Associate Professor, Teerthanker Mahaveer Institute of Management and Technology (TMIMT), Teerthanker Mahaveer University, Moradabad, UP.

Dr. Manoj Agarwal, Associate Professor, Teerthanker Mahaveer Institute of Management and Technology (TMIMT), Teerthanker Mahaveer University, Moradabad, UP

Dr. Rachit Agarwal, Director, United Resourcing Services Pvt. Ltd.

Dr Vibhor Jain, Associate Professor, Teerthanker Mahaveer Institute of Management and Technology (TMIMT), Teerthanker Mahaveer University, Moradabad, UP. with low turnover. Currently, however, they have also been following the lead of private sector banking in the Indian financial market in implementing a digital banking system. From e-wallets to net banking, all sort of things have been implemented and are open for the public.

Despite of the fact that digitalization has generated a feeling of freedom in banking certain security issues are still unknown to a certain section of the public. The lack of computer-related knowledge and discomfort of uneducated user of these facilities is another major reason for resistance to digital banking. Cash free banking is the need for the hour and must catch up with all the banks if they hold aside constraints that can be managed in the long term. The notion of electronic banking applies mainly to retail banking in a certain way. In general, the requirements of every end user for whom a customized product is produced are required to be prioritized for the digital banking. Thus, retail customers ' awareness needs to be monitored and their issues properly addressed in order to ensure digital banking performance.

\section{REVIEW OF LITERATURE}

In order to verify the knowledge and expectations of retail client towards digital banking products, a number of studies were carried out in the banks in particular and researchers in general. A variety of factors affecting Internet banking use by Australia have been analyzed by Milind S (1999). He found that security concerns and the lack of awareness were main barriers to the adoption of internet banks in Australia, in a sample of the residents and businesses.

In Indian banks, Mittal and Rajeev (2001) researched E-CRM. The analysis emphasized the value of E-CRM, its present state, its methods and future prospects used by banks in India. The conclusion was that consumers cannot rely solely on e-banking for high-end products, while people want to visit their conventional landmarks and mortar outlets for social relationships. E-CRM's success depends on reliable, scalable infrastructure development, e-commerce capability, cost reductions by increased productivity, reduced sophistication and the integration of core services.

In the field of online banking, Avinandan (2003) has researched the function of retail bank transactions with his customers. He found that shared value is important for building trust and for establishing relationships with about 500 Internet users from different profiles in India. The study also concluded that opportunistic behavior has a significant adverse effect, highlighting that communication has a moderate influence on confidence.

Published By:

Blue Eyes Intelligence Engineering 
With a view of evaluating Internet banking (e-banking) facilities in India, Sadique and Sankar (2009) conducted a study from the customer perspective. Different target audiences were given a formal questionnaire comprising 44 quality items. The key component variable analyzes were also used to determine reliability, availability, user-friendliness, privacy / security, performance, response and compliance. The findings suggest that clients are pleased with the quality, but not satisfied with "user-friendliness," for dimensions such as reliabilities, usability, confidentiality and security.

The challenges and viewpoints of e-banking have been discussed by Ruby and Pankaj (2011) thus reflecting on the benefits and risks of the electronic banking. The study concluded that e-banking provides a higher level of convenience to manage everyone's finances using a secondary source of information. Nevertheless, financial security and personal privacy have remained threatened, as many individuals had their account details compromised due to online banking.

In the scope of Internet banking adoption, Ankit and Singh (2012) have performed an analysis in India of the effect of the Technology Acceptation Model (TAM) on the security and privacy risk. With Davis's suggested Theoretical Base TAM, the paper showed that perceived risk had an adverse effect on the psychological intent of embracing Internet banking. It was also observed that a well-built Website encourages easy use and minimizes potential risks about the use of Internet banks.

The effects of cashless banking on the Nigerian economy was explored by Simeon and Bamidele (2012), using an international perspective. The study found that the move to cashless Nigeria seemed useful, although it showed a high level of concerns about security and cost savings management resulting from its implementation. It employed descriptive statistics to highlight the effectiveness of the Nigerian CBN's cashless policy.

Vishal et al. (2012) analyzed mobile banking consumer views and expectations in India with an emphasis on activities, threats and security related concerns. The study found that' mobile telephone settings' were an important problem in mobile banking, as various smartphone models supporting different types of technology on the market were available, using a quota arrangement of 50 users and 50 non-users of Ghaziabad city.

In an attempt to assess environmental sustainability by green banking, Rambalak and Swaroop (2013) published a report on private and government banks in India. The top-performing private and public banks (based on net profit) are listed for this reason. The study concluded that most banks embraced and focused only on green initiatives which offer the bank a win - win situation.

In the review of Digital Banking Migration engines for India, Chandrawati and Pandey (2017) carried out a study. E-Technology is a mechanism to promote management, strategic plans, customer service and other functions of the banks. The study found that digitisation has changed the face of branch banking and mobile technology is gradually used as a primary banking medium by exploratory analysis. However, social media convergence as its online platforms was an important driver for the transition of electronic banking.

The key factors responsible for implementing electronic (e-payment) schemes in India have been analyzed by Sahu and Kumar (2017). 13 successful variables including: confidentiality, bank participation, locker, technology, accessibility, groups, visibility, transaction range, risk, safety, transfer limits and transfer time are responsible for implementing successfully digital payments in Allahabad City. A full-length literacy study was carried out and interviews and expert opinions were used.

The scholars around the world have undertaken a vast number of studies to assess the electronic effect on banking. But the researches on a particular bank's digital products are not so fashionable. HDFC Bank, the pioneer in private banking, has established a wide variety of online bank facilities for' World Class Banking' including web banking, mobile banking, payzapp, chillr app POS, etc. Such services led to the bank's loyal customers and the creation of a major market share in India. This research focuses however on HDFC's online banking services. This paper is focused on HDFC's client's expectations for online banking, as well as to track its knowledge of the bank's digital facilities.

\section{OBJECTIVES OF THE STUDY}

The aim of the study is to enhance the perception of consumer expectations in terms of banking operations and remind them of the digital services and resources/facilities provided by the HDFC bank so that it can establish a strong digital imprint in the souk.

\section{RESEARCH METHODOLOGY}

Primary data is the base of this study. The concise inquiry model is used to gain insight into potential and actual customers of the bank. Inhabitants of the Moradabad district were taken as the target population. The approach for the sampling the non-probability technique was used to pick 266 clients as respondents and non-customers of different disciplines and ages. A well-structured questionnaire was designed to gather the data on digital banking facilities that are being offered by HDFC Bank. Researcher also focused upon comments mentioned by the customers to consider their preferences and aspirations. Therefore, both the personal and the factual aspect were the part of the questionnaire. The statistics package for social sciences (SSPS) was used to analyze data and get results of chi-square, descriptive statistics and pie-charts.

\section{DATA ANALYSIS AND INTERPRETATION}

Firstly, a questionnaire reliability test was conducted to set up a strong digital footprint for the HDFC bank. The survey was administered on fourteen questions. Cronbach's alpha is an intrinsic coherence metric (reliability) that is used on the questionnaire on several Likert scale questions. 
That decides if the measurement is accurate. It is measured The value of alpha is shown in Table 1 as 0.872 , which indicates better coherence of the measure used in the questionnaire.

\begin{tabular}{|c|c|c|}
\hline \multicolumn{3}{|c|}{ Table 1: Reliability Test } \\
\hline $\begin{array}{c}\text { Cronbach's } \\
\text { Alpha }\end{array}$ & $\begin{array}{c}\text { Cronbach's Alpha Based } \\
\text { on Standardidizel Items }\end{array}$ & No. of Items \\
\hline 0.711 & 0.872 & 14 \\
\hline
\end{tabular}

\section{Descriptive Statistics}

Table 2 displays the respondents' descriptive statistics.

Of the 266 participants, $152(57.1 \%)$ were men and 114 $(42.9 \%)$ were women

$\checkmark 2.3 \%$ of the participants were under the age of 18

$\checkmark 63.2 \%$ of the participants were between the age of $18-29$

$\checkmark 27.8 \%$ of the participants were between 30-49 years of age

$\checkmark 2.3 \%$ of those surveyed between the ages of 50-59

$\checkmark 4.5 \%$ are above the age of 60

$\checkmark 6.8 \%$ of those who answered were entrepreneurs,

$\checkmark 39.1 \%$ were in service

$\checkmark 2.3 \%$ were housewives

$\checkmark 45.1 \%$ were students

$\checkmark 6.8 \%$ participants were from other classes.

Out of 266 participants, 158 participants (59.4\%) were having banking with HDFC Bank whereas 108 participants (40.6\%) were non-customers of HDFC Bank.

\begin{tabular}{|c|c|c|c|}
\hline \multicolumn{2}{|c|}{ Descriptive } & \multirow{3}{*}{$\begin{array}{c}\mathbf{F} \\
152 \\
114 \\
\end{array}$} & \multirow{3}{*}{$\begin{array}{c}\% \\
57.14 \% \\
42.86 \% \\
\end{array}$} \\
\hline \multirow[b]{3}{*}{ 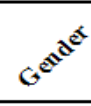 } & Women & & \\
\hline & Men & & \\
\hline & Total & 266 & $100.00 \%$ \\
\hline \multirow[b]{3}{*}{$c^{5}$} & Yes & 158 & $59.40 \%$ \\
\hline & No & 108 & $40.60 \%$ \\
\hline & Total & 266 & $100.00 \%$ \\
\hline \multirow{6}{*}{$\sigma^{e^{\circ}}$} & Entrepreneur & 18 & $6.77 \%$ \\
\hline & Service & 104 & $39.10 \%$ \\
\hline & Housewife & 6 & $2.26 \%$ \\
\hline & Student & 120 & $45.11 \%$ \\
\hline & Other & 18 & $6.77 \%$ \\
\hline & Total & 266 & $100.00 \%$ \\
\hline \multirow{6}{*}{ 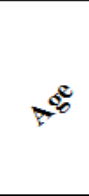 } & Below 18 & 6 & $2.26 \%$ \\
\hline & $18-29$ & 168 & $63.16 \%$ \\
\hline & $30-49$ & 74 & $27.82 \%$ \\
\hline & $50-59$ & 6 & $2.26 \%$ \\
\hline & 60 and above & 12 & $4.51 \%$ \\
\hline & Total & 266 & $100.00 \%$ \\
\hline
\end{tabular}

\section{Banks Preferred other than HDFC Bank}

The participants were told to pick banks besides HDFC banks where they already have accounts they had the option of choosing more than one bank according to their applicability. The maximum, i.e. $28.1 \%$, preferred the State Bank of India, which comprises 74 of 266 participants followed by PNB with $15.7 \%$ (42 of 266). This indicates that customers prefer public banks against private banks. (Tables 3 and 4).

\begin{tabular}{|l|c|c|}
\hline \multicolumn{3}{|c|}{ Table 3: Preferred banks of respondents. } \\
\hline Preferred Banks & $\mathrm{N}$ & Percent \\
\hline SBI & 75 & $28.10 \%$ \\
PNB & 42 & $15.69 \%$ \\
Yes bank & 16 & $5.88 \%$ \\
Axis bank & 19 & $7.19 \%$ \\
ICICI bank & 21 & $7.84 \%$ \\
Canara bank & 12 & $4.58 \%$ \\
Bank of baroda & 2 & $0.65 \%$ \\
Union bank & 9 & $3.27 \%$ \\
IDBI bank & 5 & $1.96 \%$ \\
OBC & 7 & $2.61 \%$ \\
Kotak mahindra & 3 & $1.31 \%$ \\
Vijaya bank & 3 & $1.31 \%$ \\
Central bank & 3 & $1.31 \%$ \\
Punjab gramin & 5 & $1.96 \%$ \\
Syndicate bank & 2 & $0.65 \%$ \\
Cooperative bank & 3 & $1.31 \%$ \\
Punjab and sind & 2 & $0.65 \%$ \\
Dena bank & 2 & $0.65 \%$ \\
Paytm & 3 & $1.31 \%$ \\
None & 31 & $11.76 \%$ \\
\hline Total & 266 & $100.00 \%$ \\
\hline
\end{tabular}

Table 4: Frequency of bank visit

\begin{tabular}{|l|c|c|c|}
\hline \multicolumn{1}{|c|}{ Frequency of visit } & Frequency & Percent & Cumulative Percent \\
\hline everyday & 4 & $1.5 \%$ & $1.5 \%$ \\
every alternate day & 4 & $1.5 \%$ & $3.0 \%$ \\
twice a week & 8 & $3.0 \%$ & $6.0 \%$ \\
once a week & 24 & $9.0 \%$ & $15.0 \%$ \\
thrice a month & 16 & $6.0 \%$ & $21.1 \%$ \\
twice a month & 44 & $16.5 \%$ & $37.6 \%$ \\
once a month & 54 & $20.3 \%$ & $57.9 \%$ \\
less than once a month & 96 & $36.1 \%$ & $94.0 \%$ \\
Never & 16 & $6.0 \%$ & $100.0 \%$ \\
\hline \multicolumn{2}{|c|}{ Total } & $\mathbf{2 6 6}$ & $\mathbf{1 0 0 . 0 \%}$ \\
\hline
\end{tabular}

\section{Frequency of Bank Branch Visit}

Majority of the participants choose less than once a month with $36.1 \%$ (i.e. 96 out of 266 respondents), once a month with $20.3 \%$ (i.e. 54 out of 266 respondents), twice a month with $16.5 \%$ (i.e. 44 out of 266 respondents), $9 \%$ with once a week, $6 \%$ for thrice a month, $3 \%$ twice a week and every day and every alternate day standing at $1.5 \%$ each.

As contrast was made between the visitor rate of the HDFC Bank and its customers and non-customers with 56 out of 158 customers and 40 out of 108 non-consumers, the highest number of respondents visited its bank branch more than once a month. This ensures that all clients, irrespective of the bank they want, visit their branch less than a month. Moreover, the visiting frequency for HDFC banks ' customers and non-customers is shown in Table 5 in order to see whether there is a significant difference between HDFC customers ' and non-HDFC bank customers ' visiting frequency in particular.

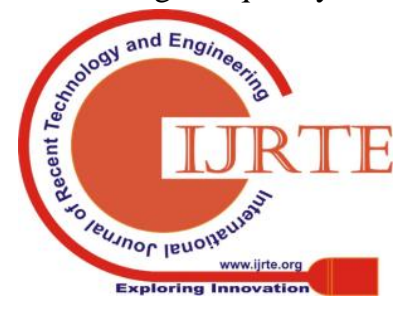


T-test was used to analyse this data. This also reported that the visits to their respective bank branches do not make any significant difference between two groups

\begin{tabular}{|c|c|c|c|c|c|c|c|c|c|c|}
\hline \multicolumn{10}{|c|}{ Table 5: Comparative analysis. } \\
\hline HDFC account & \multicolumn{10}{|c|}{ Branch visit frequency } \\
\hline & Everyday & $\begin{array}{c}\text { Every } \\
\text { alternate } \\
\text { day }\end{array}$ & $\begin{array}{c}\text { Twice } \\
\text { a week }\end{array}$ & $\begin{array}{c}\text { Once } \\
\text { a }\end{array}$ & $\begin{array}{c}\text { Thrice } \\
\text { week }\end{array}$ & $\begin{array}{c}\text { Twice } \\
\text { anth }\end{array}$ & $\begin{array}{c}\text { Once } \\
\text { a } \\
\text { month }\end{array}$ & $\begin{array}{c}\text { Less } \\
\text { a } \\
\text { thanth } \\
\text { monce a } \\
\text { month }\end{array}$ & Never & Active \\
Margin & \\
\hline Yes & 2 & 4 & 6 & 18 & 14 & 26 & 26 & 56 & 6 & 158 \\
\hline No & 2 & 0 & 0 & 6 & 2 & 20 & 28 & 40 & 10 & 108 \\
\hline Active Margin & 4 & 4 & 6 & 24 & 16 & 46 & 54 & 96 & 16 & 266 \\
\hline
\end{tabular}

\section{Reasons for visiting the Branch}

Almost all of the participants visit the banks to deposit funds with the banks $(40.5 \%)$, preceded by a $16.3 \%$ query for the bank balance and $14.4 \%$ goes to take advice for investment and $14 \%$ for transfer of funds. The information is gathered via a query of multiple kinds in which the respondents choose several ways to response (Tables 6 and 7).

\begin{tabular}{|l|c|c|c|}
\hline \multicolumn{4}{|c|}{ Table 6: Independent samples test } \\
\hline & \multicolumn{3}{|c|}{ t-test for Equality of Means } \\
\hline & $\mathrm{T}$ & $\mathrm{df}$ & Sig. (2-tailed) \\
\hline $\begin{array}{l}\text { Equal variances } \\
\text { assumed }\end{array}$ & 0.751 & 16 & 0.456 \\
\hline $\begin{array}{l}\text { Equal variances } \\
\text { not assumed }\end{array}$ & 0.751 & 15.532 & 0.456 \\
\hline
\end{tabular}

\begin{tabular}{|c|c|c|c|}
\hline \multicolumn{4}{|c|}{ Table 7: Reasons of branch visit } \\
\hline \multirow{2}{*}{ Reasons of visit the branch } & Responses & \multirow[b]{2}{*}{ Percent } & \multirow[b]{2}{*}{ Percent of Cases } \\
\hline & $\mathrm{N}$ & & \\
\hline Make deposit & 108 & $40.60 \%$ & $66.4 \%$ \\
\hline Advice for investment & 38 & $14.29 \%$ & $23.7 \%$ \\
\hline Fund transfer & 37 & $13.91 \%$ & $22.9 \%$ \\
\hline Inquire balance & 43 & $16.17 \%$ & $26.7 \%$ \\
\hline Order cheque book & 28 & $10.53 \%$ & $17.6 \%$ \\
\hline Locker & 1 & $0.38 \%$ & $0.8 \%$ \\
\hline Passbook update & 3 & $1.13 \%$ & $1.5 \%$ \\
\hline Nil & 8 & $3.01 \%$ & $4.6 \%$ \\
\hline Total & 266 & $100.00 \%$ & $164.10 \%$ \\
\hline
\end{tabular}

\section{Digital Banking}

The survey participants were asked if electronic banking is being used or not. 186 (69.9 percent) out of a total number of 266 respondents reported using either form of digital banking, while 80 (30.1 percent) reported not using digital banking. (Table 8).

\begin{tabular}{|l|c|c|c|}
\hline \multicolumn{4}{|c|}{ Table 8: Use of digital banking } \\
\hline & Frequency & Percent & Cumulative Percent \\
\hline Yes & 186 & 69.9 & 69.9 \\
No & 80 & 30.1 & 100 \\
\hline Total & $\mathbf{2 6 6}$ & $\mathbf{1 0 0}$ & \\
\hline
\end{tabular}

The age group of 18-29 years used peak digital banking (78.6 percent) when a comparative study was conducted between age and use of digitalization for a clearer view (Table 9 ). While the 50-59 and over 60 years old age groups are $66.7 \%$ and $100 \%$ respectively with the least digital banking uses. The chi-square results show a value of 20.548 with 4 degrees of freedom and a value of $7 \%$ of significance. This suggests that ageing is a significant factor in the use of electronic banking services, since younger people are more technically advanced compared to people of other ages (Table 10).

\begin{tabular}{|l|c|c|c|c|}
\hline \multicolumn{4}{|c|}{ Table 9: Age-wise comparative analysis } \\
\hline \multicolumn{1}{|c|}{ Age } & \multicolumn{2}{|c|}{ Digital banking } & \multicolumn{2}{c|}{ Percentage } \\
\hline & Yes & No & Yes & No \\
\hline below 18 & 2 & 4 & $33.3 \%$ & $66.7 \%$ \\
$\mathbf{1 8 - 2 9}$ & 132 & 36 & $78.6 \%$ & $21.4 \%$ \\
$\mathbf{3 0 - 4 9}$ & 50 & 24 & $67.6 \%$ & $32.4 \%$ \\
$\mathbf{5 0 - 5 9}$ & 2 & 4 & $33.3 \%$ & $66.7 \%$ \\
$\mathbf{6 0}$ and above & 0 & 12 & - & 100 \\
\hline Active Margin & 186 & 80 & 69.9 & 30.1 \\
\hline
\end{tabular}

\begin{tabular}{|c|c|c|c|c|c|c|c|}
\hline \multicolumn{8}{|c|}{ Table 10: Chi Square analysis. } \\
\hline \multirow{2}{*}{ Dimension } & \multirow{2}{*}{$\begin{array}{l}\text { Singular } \\
\text { Value }\end{array}$} & \multirow{2}{*}{ Inertia } & \multirow{2}{*}{ Chis Square } & \multirow{2}{*}{ Sig. } & \multicolumn{2}{|c|}{ Propotition of Inertia } & Confidence Singular \\
\hline & & & & & $\mid \begin{array}{c}\text { Accounted } \\
\text { for }\end{array}$ & Cumulative & e. Standard Deviation \\
\hline 1 & 0.396 & 0.157 & & & 1 & 1 & 0.072 \\
\hline Total & & 0.157 & 20.548 & $0.000 \mathrm{a}$ & 1 & 1 & \\
\hline
\end{tabular}

\section{Reasons for Not Using Digital Banking}

The factor many customers opted not to use online banking was because they were "not interested" with 27.5 percent preceded by the explanation they "don't get time" with 25 percent and with 20 percent difficult to access (Table 11). 


\begin{tabular}{|l|c|c|c|}
\hline \multicolumn{4}{|c|}{ Table ll: Reasons of not using digital banking. } \\
\hline Reasons for not using digital bank & Frequency & Percent & Cumulative Percent \\
\hline Not aware about it & 14 & $17.5 \%$ & 17.5 \\
Concerned about security & 4 & $5.0 \%$ & 22.5 \\
Dificult to access & 16 & $20.0 \%$ & 42.5 \\
Don't get time & 20 & $25.0 \%$ & 67.5 \\
No computer related knowledge & 4 & $5.0 \%$ & 72.5 \\
Not interested & 22 & $27.5 \%$ & 100 \\
\hline \multicolumn{1}{|c|}{ Total } & 80 & $100.0 \%$ & \\
\hline
\end{tabular}

The other reasons were 'not aware about digital banking' with $17.5 \%$ and concerned about security along with the reason that 'no computer knowledge' standing at 5\% each (Figure 1).

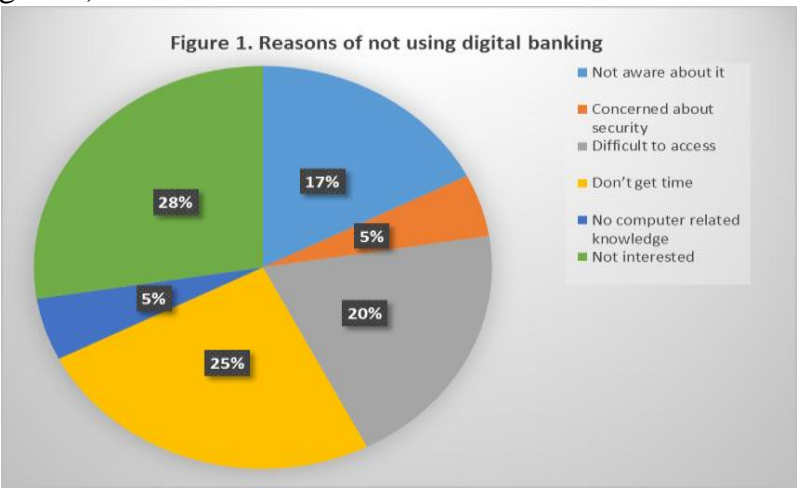

\section{Uses of Digital Banking Reasons}

The main two reasons given by customers were "convenient" (38.4 percent) and "time saver" (31 percent) when participants who use digital banking were asked to give reasons for using digital banking. These were preceded by "safe and secure" (11.6\%), "better discount offers" (10.3\%) and "better management of cash flow" (8.2\%) (Table 12).

\begin{tabular}{|l|c|c|}
\hline \multicolumn{2}{|c|}{ Table 12: Reasons of using digital banking } \\
\hline \multirow{2}{*}{ Reasons of using } & \multicolumn{2}{|c|}{ Responses } \\
\cline { 2 - 3 } & $\mathrm{N}$ & Percent \\
\hline Convenient & 71 & $38.17 \%$ \\
Saves time & 59 & $31.72 \%$ \\
Safe and Secure & 22 & $11.83 \%$ \\
Better offers discounts & 19 & $10.22 \%$ \\
Cash flow management & 15 & $8.06 \%$ \\
\hline \multicolumn{1}{|c|}{ Total } & 186 & $100.00 \%$ \\
\hline
\end{tabular}

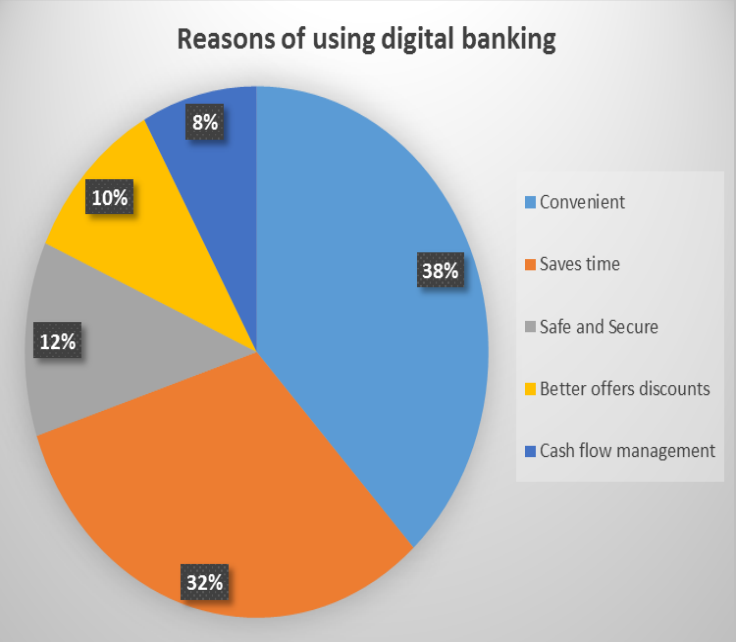

Digital Banking Facilities

The participants were asked whether they were aware of HDFC's digital banking facilities like: mobile banking, net banking, debit card, credit card, POS machines, Smartbuy, Payz app and Chillr. Analysis for the same is as under:

Net banking, mobile banking and credit card: Table 13 evaluates participant understanding of HDFC Bank's mobile banking, credit card and internet banking facilities. A net banking system is used by $63.29 \%$ of HDFC customers while $36.71 \%$ of their customers are aware of this facility. This indicates that no one of the HDFC bank's customers is unaware of the HDFC Bank's net bank facility. Nonetheless, $24.07 \%$ of people do not know about net banking as a representation of potential clients of the HDFC bank. 56.96\% of HDFC bank customers use mobile banking, while $35.44 \%$ are conscious but do not use this service. This service provided by the bank is not known to 7.59 percent of people. 22.22 percent of 108 non-customers do not know of HDFC's mobile banking network. With respect to the credit card facility, all the customers use or are well conscious of the service provided by HDFC bank. Credit cards are used by 30.8 percent of respondents and by 60.2 percent of respondents. Of the 266 participants, only 24 were ignorant for credit card, that is to say $9 \%$. Nevertheless, this institution offered by the bank in the no-customer class is not recognized to $22.22 \%$ of people. Briefly, people are familiar with HDFC Bank's web banking, mobile banking and credit card facilities.

\begin{tabular}{|c|c|c|c|c|c|}
\hline \multicolumn{6}{|c|}{ 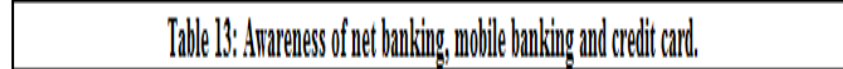 } \\
\hline & 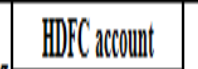 & Illowile & BDFC Canount & & $\mathbb{B D P C}$ encount \\
\hline & 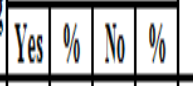 & manking & 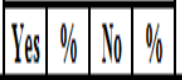 & & 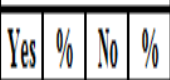 \\
\hline ex, $15 \mathrm{se}$ & $\mid 10062.20$ & $\mathrm{Ves}_{\mathrm{e}, \text { weit }}$ & $906609+3$ & Ies, weit| & 80030.62 .11 \\
\hline Yes & 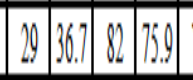 & VES & 361354.4017 & Ves & $78(493)(8217$ \\
\hline & \begin{tabular}{|l|l|l|l|l|}
18 & 0 & 26 & 24.1 \\
\end{tabular} & 10 & 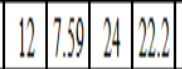 & & \begin{tabular}{l|l|l|l|l|l|}
0 & 0 & 24 \\
\end{tabular} \\
\hline & & & & & $m+$ \\
\hline
\end{tabular}




\section{Debit card, Chillr and Payz app:}

The bank's debit card facility is well known to all HDFC clients, and it is utilized by 88.61 percent of clients (Table 14). A debit card is used by $59.4 \%$ of participants and $36.1 \%$ of participants understand this service. $63.29 \%$ and $56.96 \%$ of current customers, respectively, are unsure of these services for the use of Chillr and Payz App. Chillr and Payz app are used respectively by only 17.72 percent and 20.25 percent of users. It is clear from the table that the unawareness percentage about Chillr is $79.63 \%$ and that of Payz app is $83.33 \%$ to a non-customers of HDFC bank. This signifies that the bank must make people conscious of the advanced technologies such as the bank's Chillr and Payz app. In contrast, the Bank should also use the new digital services from its existing customers.

\begin{tabular}{|c|c|c|c|c|c|}
\hline \multicolumn{6}{|c|}{ 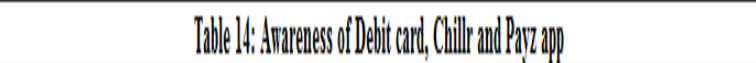 } \\
\hline \multirow{2}{*}{ Debit and } & $\mathbb{B D F}$ Caccount & \multirow{2}{*}{ Chill' } & $\mathbb{B D F}$ Cacoumt & \multirow{2}{*}{ Pązір } & $\mathbb{D P F}$ Caccount \\
\hline & 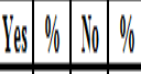 & & 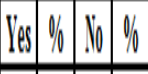 & & 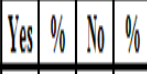 \\
\hline Ves, useit & 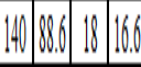 & Ves, wseit & \begin{tabular}{|l|l|l|l|l|}
28 & 17.2 & 2 & 1.85 \\
\end{tabular} & Ves, weseit & 32.20 .20 \\
\hline Ves & \begin{tabular}{l|l|l|l|}
18 & 11.3 & 78 & 72.2 \\
\end{tabular} & & \begin{tabular}{|l|l|l|l|l|}
30 & 180 & 20 & 18.5 \\
\end{tabular} & & \begin{tabular}{|l|l|l|l|l|}
36 & 22.7 & 18 & 160. \\
\end{tabular} \\
\hline 10 & \begin{tabular}{l|l|l|l|l}
0 & 0 & 1.12 & 11.1 \\
\end{tabular} & & \begin{tabular}{|l|l|l|l|}
100 & 63.2 .2 & 86 & 79.6 \\
\end{tabular} & & 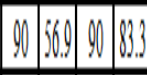 \\
\hline & & & & & \\
\hline
\end{tabular}

\section{Smartbuy, POS machine:}

Table 15 reveals only a few customers using the HDFC bank's smart buy-in platform $(12.66 \%)$ and POS hardware. These facilities provided by HDFC Bank would otherwise not be identified to most people in general or consumers in the bank.

\begin{tabular}{|l|c|c|c|c|c|c|c|c|c|}
\hline \multicolumn{7}{|c|}{ Table 15: Awareness of smart buy and POS machine. } \\
\hline \multirow{2}{*}{ Smart buy } & \multicolumn{3}{|c|}{ HDFC account } & \multirow{2}{*}{ POS machine } & \multicolumn{3}{|c|}{ HDFC account } \\
\cline { 2 - 7 } & Yes & $\%$ & $\mathrm{~N}_{0}$ & $\%$ & & Yes & $\%$ & $\mathrm{~N}_{0}$ & $\%$ \\
\hline Yes, use it & 20 & 12.7 & 0 & 0 & Yes, use it & 30 & 19 & 0 & 0 \\
\hline Yes & 42 & 26.6 & 22 & 20.4 & Yes & 32 & 20.3 & 18 & 16.7 \\
\hline$N_{0}$ & 96 & 60.8 & 86 & 79.6 & $\mathrm{~N}_{0}$ & 96 & 60.8 & 90 & 83.3 \\
\hline Active Margin & 158 & 100 & 108 & 100 & Active Margin & 158 & 100 & 108 & 100 \\
\hline
\end{tabular}

Objective of use of electronic banking: The participants were asked to clarify the factors/reasons for using internet banking. The participants were allowed to choose from multiple choice options. The majority of participants $24 \%$ opted "to check the balance", $23.7 \%$ opted "bill payment" and $14.1 \%$ opted "to review the account statement. Table 16 outlines the other explanations.

\begin{tabular}{|c|c|c|}
\hline Table 16: Purpose of & $\lg \mathbf{E}-$ & king \\
\hline \multirow{2}{*}{ Purpose } & \multicolumn{2}{|c|}{ Responses } \\
\hline & $\mathbf{N}$ & Percent \\
\hline Check balance & 64 & $24.06 \%$ \\
\hline Liquidate & 13 & $4.89 \%$ \\
\hline Account statement & 37 & $13.91 \%$ \\
\hline Cheque status & 19 & $7.14 \%$ \\
\hline Request cheque book, DD & 11 & $4.14 \%$ \\
\hline Tax e-filling & 15 & $5.64 \%$ \\
\hline Bill payments & 63 & $23.68 \%$ \\
\hline Mutual funds & 7 & $2.63 \%$ \\
\hline Demat account & 6 & $2.26 \%$ \\
\hline Avail discounts & 15 & $5.64 \%$ \\
\hline Open FD or RD & 16 & $6.02 \%$ \\
\hline Total & 266 & 100 \\
\hline
\end{tabular}

quency of using e-banking: Net Banking was used by most respondents approximately 1-3 times a month, with 24.7 percent followed by 5-10 times a month, and 21.5 percent. The other options included less than one (19.4\%), 3 to 5 times (18.3\%) and 10 times (16.1\%) (Figure 2 and Table 17).

\begin{tabular}{|l|c|c|c|}
\hline \multicolumn{4}{|c|}{ Table 17: Frequency of using E-banking } \\
\hline & Frequency & Percent & Cumulative Percent \\
\hline Less than one time & 36 & $19.4 \%$ & 19.4 \\
$1-3$ times & 46 & $24.7 \%$ & 44.1 \\
$3-5$ times & 34 & $18.3 \%$ & 62.4 \\
$5-10$ times & 40 & $21.5 \%$ & 83.9 \\
More than 10 times & 30 & $16.1 \%$ & 100 \\
\hline \multicolumn{1}{|c|}{ Total } & $\mathbf{1 8 6}$ & $\mathbf{1 0 0}$ & \\
\hline
\end{tabular}

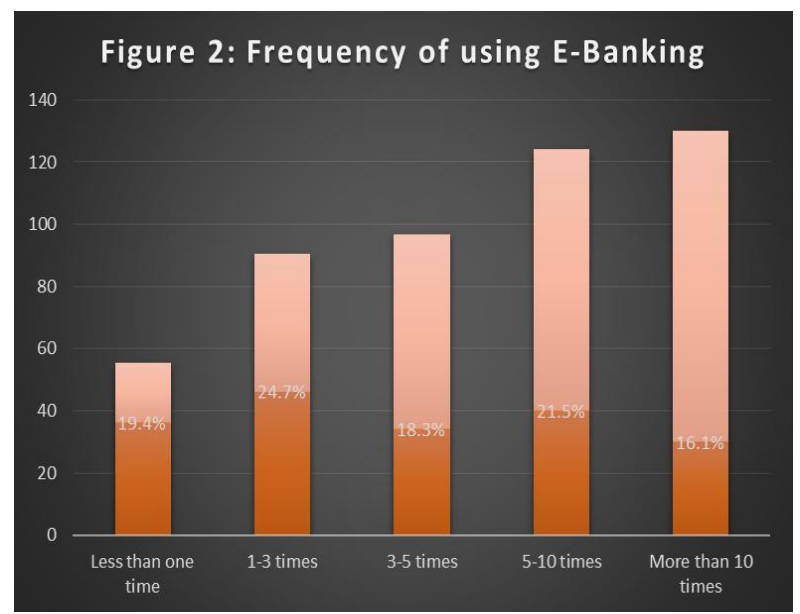

VI. CONCLUSION

The online mega movement has a tremendous global impact on business and with the launch of a large number of digital innovative products; the HDFC Bank is a leading participant. A research has therefore been conducted to test customers ' knowledge and expectations for digital products provided by HDFC bank. In this regard, current and potential HDFC Bank customers have been considered. 
The data was obtained by means of questionnaires and analyzed by SPSS. As per the findings of the study, the customers use to give more preference to government banks like SBI and PNB apart from HDFC. That implies that public sector banking is still like on and over the private sector banking by the people. But when it comes to digital banking system, consumers' age group plays an influential factor in the use of online banking. People aged 18-29 years with computer-based services are most comfortable because of their comfort and time-saving. Net banking, mobile banking, debit cards and credit cards are the most popular electronic services of the HDFC bank. But other innovative products such as smart buy, payz, chillr and POS are not well recognized. The bank therefore should actively advertise its services and encourage customers to purchase their goods through different deals and promotions. In order to draw the highest audience, selling such goods should be achieved through digital media, in particular televised media.

E-banking is mainly intended to check the balance of the account, to pay your bills and to access the account statement from your own computer. The bank focused on brick and mortar is growing over time, as the study shows, while most people visit their branches within a month. Cash deposits and seeking advice on investing were the main reasons for visiting the branch.

If communications are carried out between respondents via one contact, the safety of their funds as cyber theft prevails during the digitization period was their main concerns with regard to the digitization of the banking system. Another primary reason was that some people do not have the know-how to run such services. Tutorials for use of e-banking should therefore be given especially for the uneducated or elderly. To order to monitor theft or failure of the electronic banking, an urgent complaints-addressing system should be in operation.

\section{REFERENCES}

1. Milind S (1999) Adoption of Internet banking by Australian consumers: an empirical investigation. International Journal of Bank Marketing 17: 324-334.

2. Mittal RK, Rajeev K (2001) E-CRM in Indian banks. Delhi Business Review, V: 2

3. Avinandan M (2003) A model of trust in online relationship banking. International Journal of Bank Marketing 21: 5-15.

4. Sadique KM, Sankar MS (2009) Service quality evaluation in internet banking: an empirical study in India. International Journal of Indian Culture and Business Management, V: 2.

5. Ruby S, Pankaj S (2011) E-Banking: Problems and Prospects. International Journal of Management \& Business Studies V: 1.

6. Ankit K, Singh BS (2012) The impact of trust and perceived risk on internet banking adoption in India: An extension of technology acceptance model. International journal of bank marketing 30: 303-322.

7. Simeon OE, Bamidele BF (2012) Cashless Banking in Nigeria: Challenges, Benefits and Policy Implications. European Scientific Journal 8: 289-316.

8. Vishal G, Pandey US, Sanjay B (2012) Mobile Banking in India: Practices, Challenges and Security Issues. International Journal of Advanced Trends in Computer Science and Engineering 1: 56-66.

9. Rambalak Y, Swaroop PG (2013) Environmental Sustainability through Green Banking: A Study on Private and Public Sector banks in India. OIDA International Journal of Sustainable Development 6: $37-48$.

10. Chandrawati N, Pandey BB (2017) Role of E-Banking services towards Digital India. International Journal of Commerce and Management Research 3: 67-71.

11. Sahu GP, Kumar SN (2017) Paradigm Shift of Indian Cash $\neg$ Based
Economy to Cash $\neg$ Less Economy: A Study on Allahabad City. Digital Nations-Smart Cities, Innovation, and Sustainability: 16th IFIP WG 6.11 Conference on e-Business, e-Services, and e-Society Proceedings, pp: 453-461. 